\title{
PENGARUH PRAKTIK INDUSTRI TERHADAP HARD SKILL SISWA SMK PADA PROGRAM KEAHLIAN TEKNIK PEMESINAN
}

\author{
Yudha Dwi Prasetyo" ${ }^{1}$, Tiwan ${ }^{2}$, Arianto Leman Soemowidagdo ${ }^{3}$ \\ 1,2,3 Jurusan Pendidikan Teknik Mesin Fakultas Teknik Universitas Negeri Yogyakarta \\ Email: yudhapras28@gmail.com
}

\begin{abstract}
This research aims to determine the implementation of industrial attachment for the students of machining study program, and the influence of industrial attachment on the students' hard skill. This research used ex-post facto method with a quantitative approach. The subjects were class XII students of machining study program with a total sample of 98 students. Data were collected using questionnaire and documentation. Data were analyzed using Pearson's product moment correlation and simple regression analysis. Results show that the implementation of industrial attachment for students of machining study program is categorized as 'high' (69,38\% in average), and that there is as a positive and significant effect on the students' hard skill.
\end{abstract}

Keywords: industrial attachment, hard skill, machining

\begin{abstract}
ABSTRAK
Pelaksanaan praktik industri diharapkan mampu meningkatan keterampilan, kemampuan verbal, dan dapat memberikan ide-ide kreatif bagi siswa dalam mengembangkan keterampilan yang telah dimilikinya untuk membuat inovasi produk tepat guna. Penelitian ini bertujuan untuk mengetahui keterlaksanaan praktik industri siswa Teknik Pemesinan, dan pengaruh praktik industri terhadap hard skill siswa. Penelitian ini menggunakan metode ex-post facto dengan pendekatan kuantitatif. Subyek penelitian adalah siswa kelas XII program keahlian Teknik Pemesinan dengan jumlah sampel 98 siswa. Metode pengumpulan data dengan metode kuesioner dan dokumentasi. Teknik analisis data menggunakan teknik korelasi product moment dari Pearson dan dilakukan uji analisis regresi sederhana. Hasil penelitian menunjukkan bahwa keterlaksanaan praktik industri siswa teknik pemesinan rata-rata temasuk kedalam kategori tinggi 69,38\%, dan praktik industri berpengaruh positif dan signifikan terhadap hard skill siswa. Hubungan yang diperoleh adalah semakin tinggi tingkat pelaksanaan praktik industri, maka semakin tinggi pula hard skill-nya dan bidang pekerjaan memiliki pengaruh tinggi terhadap nilai praktik industri siswa teknik pemesinan
\end{abstract}

Kata kunci: praktik industri, hard skill, teknik pemesinan

\section{PENDAHULUAN}

Kebutuhan Sumber Daya Manusia
(SDM) sebagai tenaga kerja profesional
mempunyai peranan yang sangat penting
dalam meningkatkan pembangunan ekonomi
di Indonesia. Upaya untuk memenuhi
kebutuhan sumber daya manusia tersebut maka
dibentuk lembaga pendidikan kejuruan, yang
salah satu diantaranya adalah Sekolah
Menengah Kejuruan (SMK). Pendirian SMK
dimaksudkan untuk menyiapkan kebutuhan
tenaga kerja tingkat menengah yang siap kerja
dengan bekal keterampilan yang cukup setelah

mengikuti pendidikan dan latihan. Lulusan SMK harus memiliki kompetensi sesuai dengan program keahlian yang dipilih dan siap bersaing didunia kerja (Dwi, 2015: 2).

Salah satu upaya untuk memenuhi kebutuhan tenaga kerja tersebut maka penyelenggaraan pendidikan kejuruan perlu mendidik siswanya untuk langsung terjun di dunia kerja. Program pendidikan langsung ini salah satunya adalah dalam bentuk praktik industri. Praktik Industri ini merupakan kegiatan yang harus diikuti oleh setiap siswa SMK yang dipersiapkan menjadi tenaga kerja 
yang siap untuk mengisi lapangan kerja tingkat menengah sesuai dengan bidang keahlian yang dikuasai dan ditekuninya.

Tujuan dari pelaksanaan Praktik Industri adalah: a) menghasilkan tenaga kerja yang memiliki keahlian berkualitas yaitu, tenaga kerja yang memiliki tingkat pengetahuan, keterampilan, dan etos kerja yang sesuai dengan tuntutan kebutuhan lapangan kerja, b) memperoleh link and match antara SMK dan dunia kerja, c) meningkatkan efisiensi proses pendidikan dan pelatihan tenaga kerja yang berkualitas, d) memberi pengakuan dan penghargaan terhadap pengalaman kerja sebagai bagian proses pendidikan. Dunia Usaha/Dunia Industri (DU/DI) sebagai mitra kerja sama SMK, memberikan kesempatan kepada SMK menitipkan siswanya untuk melaksanakan praktik industri. Siswa yang melaksanakan praktik industri diharapkan mampu mengimplementasikan ilmu yang didapatkan di bangku sekolah pada dunia kerja. DU/DI sebagai mitra kerja sama dengan SMK, diharapkan selain sebagai tempat praktik industri siswa, dapat juga melaksanakan kerja sama lain. Kerja sama antara sekolah dengan DU/DI, dapat berupa penyaluran lulusan, sarana dan prasarana, relevansi kurikulum, serta kerja sama lain yang tentunya dapat menguntungkan pihak DU/DI dan dapat mengembangkan SMK (Indriaturrahmi, 2016: 4).

Bantuan dari DU/DI sangat dibutuhkan oleh SMK untuk membuat siswa memiliki etos kerja sesuai dengan kebutuhan di dunia kerja. Djojonegoro (1998), menjelaskan bahwa orientasi pendidikan kejuruan membawa konsekuensi bahwa pendidikan kejuruan harus selalu dekat dengan dunia kerja. Kedekatan tersebut dalam artian bahwa perencanaan dan penyelenggaraan pendidikan kejuruan harus sesuai dengan kebutuhan dunia kerja. Salah satu faktor penentu keberhasilan penyelenggaraan pendidikan kejuruan adalah kerja sama atau kemitraan dengan DU/DI selaku penyedia lapangan kerja.
Rediyono menjelaskan bahwa upaya untuk menjalin hubungan kerjasama antara sekolah dan dunia industri mutlak diperlukan karena sejatinya pendidikan kejuruan dilaksanakan untuk memenuhi kebutuhan di industri itu sendiri. Kerjasama antara sekolah dengan industri sangat diperlukan terkait dengan perkembangan teknologi yang terjadi di industri sangat pesat sehingga sekolah akan jauh tertinggal jika tidak menjalin kerjasama dengan industri sebab pihak sekolah tidak mungkin menyediakan semua peralatan yang sesuai dengan kebutuhan industri dalam proses pembelajaran di sekolah (Djandji, 2013: 1).

Pelaksanaan praktik industri diharapkan mampu meningkatan keterampilan dan meningkatan kemampuan verbal siswa. Selain mendapatkan peningkatan keterampilan dan verbal pembelajaran praktik industri diharapkan dapat memberikan ide-ide kreatif bagi siswa dalam mengembangkan keterampilan yang dimiliki untuk membuat inovasi-inovasi produk yang berguna, layak jual, atau mampu meningkatkan keterampilan siswa. Praktik industri memiliki manfaat bagi siswa. Salah satu manfaat setelah melaksanakan praktik industri adalah meningkatnya hard skill/keterampilan siswa. Hard skill menggambarkan wawasan intelektual seseorang. Hard skill ada di otak. Hard skill biasanya diperoleh dari pendidikan formal seperti sekolah dan sumber referensi lainnya seperti bacaan atau dari sumber informasi lain seperti TV, majalah, koran, dan lainnya.

Basir (2011) berpendapat bahwa hard skill adalah kemampuan yang biasa dipelajari di sekolah atau universitas yang memiliki tujuan untuk meningkatkan kemampuan intelektual yang berhubungan dengan subyek yang dipelajari. Hard skill bisa diukur dengan melakukan tes yang ada hubungannya dengan bidang yang dipelajari. Bisa dikatakan bahwa Hard skill bersifat kasat mata atau nyata. Lehan (2014) menjelaskan bahwa praktik industri juga berpengaruh terhadap soft skill dan karier siswa, menurut Lehan variabel soft skills berpengaruh signifikan terhadap variabel 
prestasi praktik kerja industri. Selain itu, hasil penelitian Hari (2017) menyatakan bahwa Terdapat pengaruh positif dan signifikan secara bersama bimbingan karir dan praktik kerja industri terhadap kesiapan kerja siswa kelas XII Program Keahlian Teknik Pemesinan di SMK Negeri 2 Pengasih. Pendapat lain juga dikemukakan oleh Dalhari (2016) dalam hasil penelitiannya menyatakan bahwa pengalaman praktik kerja industri berpengaruh positif terhadap minat berwirausaha peserta didik kelas XII kejuruan Pengelasan SMK N 1 Pundong tahun ajaran 2015/2016, yang dibuktikan dengan hasil koefisien korelasi sebesar 0,601 dan koefisien determinasi sebesar 0,361 yang berarti pengalaman praktik industri mempengaruhi kesiapan kerja sebesar 36\%.

Berdasarkan penjelasan di atas maka perlu dilakukan penelitian lebih lanjut tentang pengaruh praktik industri terhadap hard skill siswa yang bertujuan untuk mengetahui bagaimana pelaksanaan praktik industri siswa, dan pengaruhnya terhadap hard skill siswa kelas XII khususnya pada program keahlian teknik pemesinan.

\section{METODE}

Penelitian ini menggunakan metode $e x$ post facto dengan pendekatan kuantitatif untuk mendapatkan informasi dan keterangan mengenai pelaksanaan praktik industri dan hard skill siswa kelas XII Teknik Pemesinan. Penelitian ini dilaksanakan pada Februari 2018 di SMK Muhammadiyah 1 Bantul khususnya pada kompetensi keahlian Teknik Pemesinan. Prosedur penelitian yang digunakan yaitu menggunakan kuesioner dan dokumentasi. Kuesioner digunakan untuk mengetahui hasil respon siswa, sedangkan dokumentasi digunakan untuk mengetahui identitas siswa Teknik Pemesinan, daftar nilai sebelum dan sesudah praktik industri, serta daftar nilai praktik industri siswa.

Populasi penelitian ini adalah seluruh siswa kelas XII Teknik Pemesinan SMK Muhammadiyah 1 Bantul yang berjumlah 131 siswa. Sampel penelitian yang ditentukan dengan teknik proporsional sampling karena cara pengambilan sampel pada tiap-tiap sub populasi dengan memperhitungkan besar kecilnya sub-sub populasi tersebut. Ukuran sampel ini menggunakan rumus dari Sugiyono (2013) didapatkan sampel sebanyak 98 siswa.

Teknik analisis data yang digunakan adalah teknik analisis kuantitatif. Sesuai dengan tujuan penelitian ini yaitu untuk mengetahui pengaruh praktik industri terhadap hard skill siswa teknik pemesinan, pengaruh dari bidang tempat kerja terhadap hard skill siswa, dan pengaruh bidang pekerjaan terhadap nilai praktik industri siswa. Perhitungan persentase menggunakan perhitungan kecenderungan dari Suharsimi (2013) pada Tabel 1.

Tabel 1. Kecenderungan statistik deskriptif

\begin{tabular}{ll}
\hline Kecenderungan & Kategori \\
\hline $\mathrm{X}>\mathrm{Mi}+1,5 \mathrm{SDi}$ & Sangat Tinggi \\
$\mathrm{Mi}+1,5 \mathrm{SDi}>\mathrm{X} \geq \mathrm{Mi}$ & Tinggi \\
$\mathrm{Mi}>\mathrm{X} \geq \mathrm{Mi}-1,5 \mathrm{SDi}$ & Rendah \\
$\mathrm{X}<\mathrm{Mi}-1,5$ SDi & Sangat rendah \\
\hline
\end{tabular}

Keterangan:

$\begin{array}{ll}\mathrm{X} & =\text { Mean hitungan } \\ \mathrm{Mi} & =\text { Mean Ideal } \\ \mathrm{SDi} & =\text { Standar Deviasi Ideal }\end{array}$

Analisis kecenderungan digunakan untuk mengetahui kesimpulan dari hasil penelitian yang telah dilakukan. Analisis pengaruh praktik industri terhadap hard skill menggunakan perhitungan garis regresi sederhana dengan menggunakan persamaan 1.

$$
\hat{\mathrm{Y}}=\mathrm{a}+\mathrm{bX}
$$

\section{Keterangan:}

$\hat{\mathrm{Y}}=\quad$ subjek variabel terikat yang diprediksi

$\mathrm{A}=$ harga $\mathrm{Y}$ ketika harga $\mathrm{X}=0$ (konstanta)

$\mathrm{B}=$ angka arah atau koefisien regresi, yang menunjukkan angka peningkatan ataupun penurunan variabel terikat yang disarankan pada variabel bebas. Bila b (+) maka naik, dan bila b (-) maka arah garis turun. 


\section{$\mathrm{X}=\quad$ subjek pada variabel bebas yang mempunyai nilai tertentu}

\section{HASIL DAN PEMBAHASAN}

Hasil penelitian yang didapatkan mengenai pengaruh praktik industri terhadap hard skill siswa teknik pemesinan SMK Muhammadiyah 1 Bantul melalui instrumen kuesioner dan dokumentasi.

Pelaksanaan Praktik industri siswa teknik pemesinan diperoleh data sebagai berikut, sebagaimana ditunjukkan pada Gambar 1.

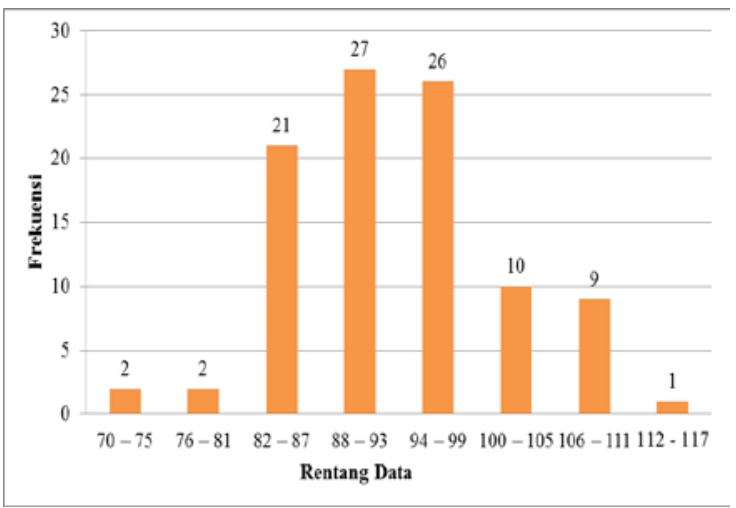

Gambar 1. Histogram pelaksanaan praktik industri

Gambar 1 menunjukkan bahwa skor kuesioner pelaksanaan praktik industri siswa dengan frekuensi terbanyak pada rentang data 88-93 dengan 27 siswa, dan frekuensi terendah dengan rentang data 112-117 terdapat 1 siswa.

Pengukuran kecenderungan pelaksanaan praktik industri dapat dilihat pada data Gambar 2.

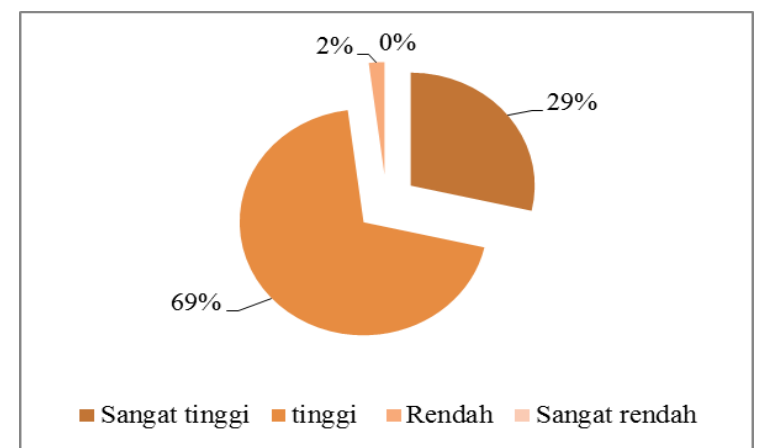

Gambar 2. Diagram lingkaran kecenderungan pelaksanaan praktik industri
Berdasarkan data pada Gambar 2 dapat disimpulkan bahwa variabel praktik industri siswa teknik pemesinan 29\% siswa termasuk kedalam kategori sangat tinggi, 69\% termasuk kategori tinggi, dan 2\% termasuk kategori rendah, sehingga pelaksanaan praktik industri siswa rata-rata termasuk kedalam kategori tinggi.

Hard Skill siswa teknik pemesinan SMK Muhammadiyah 1 Bantul dapat dilihat pada Gambar 3.

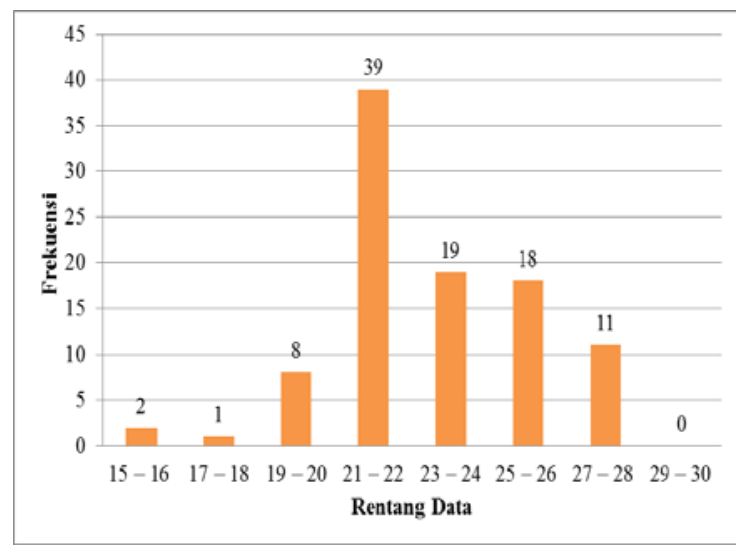

Gambar 3. Histogram hard skill siswa

Gambar 3 menunjukkan bahwa skor kuesioner hard skill siswa dengan frekuensi terbanyak terdapat pada rentang data 21-22 dengan 39 siswa, dan skor kuesioner dengan frekuensi terendah terdapat pada rentang data 17-18 dengan 1 siswa.

Pengukuran kecenderungan hard skill diperoleh data diagram pada Gambar 4.

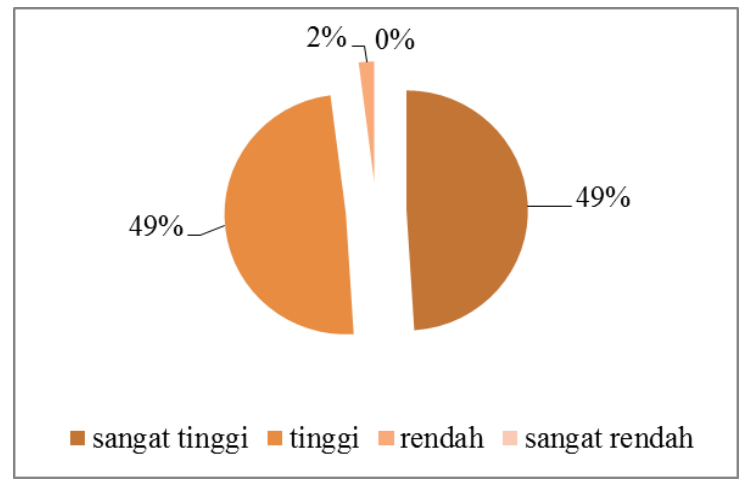

Gambar 4. Diagram lingkaran kecenderungan hard skill 
Berdasarkan data pada Gambar 4 dapat disimpulkan bahwa variabel hard skill siswa teknik pemesinan $49 \%$ siswa termasuk kedalam kategori sangat tinggi, 49\% termasuk kategori tinggi, dan 2\% termasuk kategori rendah, sehingga hard skill siswa rata-rata termasuk kedalam kategori tinggi. Selain data di atas disajikan data nilai sebelum praktik industri dan sesudah praktik industri. Diperoleh data pada Gambar 5.

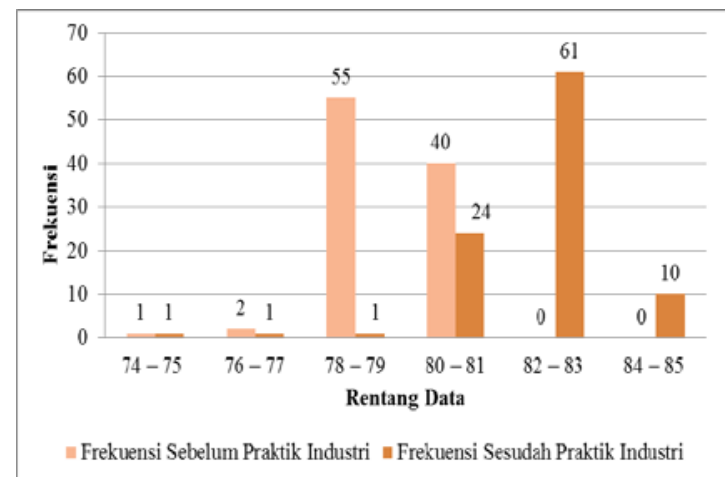

Gambar 5. Histogram nilai sebelum dan sesudah praktik industri

Berdasarkan data tersebut dapat disimpulkan bahwa terjadi peningkatan hard skill siswa setelah melaksanakan praktik industri.

Disajikan data diagram pembagian bidang tempat praktik industri, dapat dilihat pada Gambar 6. Data tersebut dapat diketahui bahwa bidang tempat praktik industri terbanyak pada bidang pengelasan dengan 52\%, pemesinan $32 \%$, pemesinan serta pengelasan 8\%, dan lainnya $8 \%$.

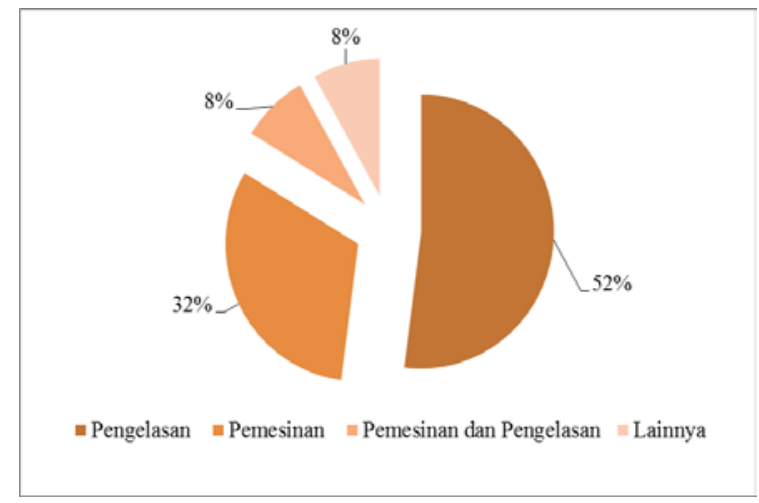

Gambar 6. Diagram lingkaran penyebaran bidang tempat praktik industri
Disajikan data penyebaran bidang pekerjaan yang ditempat praktik industri, dapat dilihat pada Gambar 7.

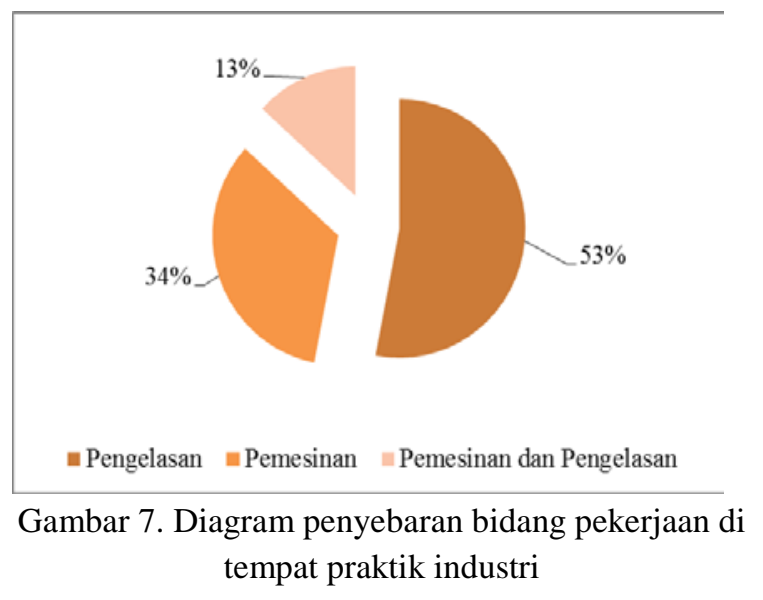

Dari data tersebut dapat diketahui bahwa bidang pekerjaan paling banyak adalah pengelasan dengan 53\%, pemesinan $34 \%$, dan pemesinan dan pengelasan 13\%. Kemudian disajikan data nilai praktik industri siswa sesuai bidang pekerjaannya, dapat dilihat pada Gambar 8.

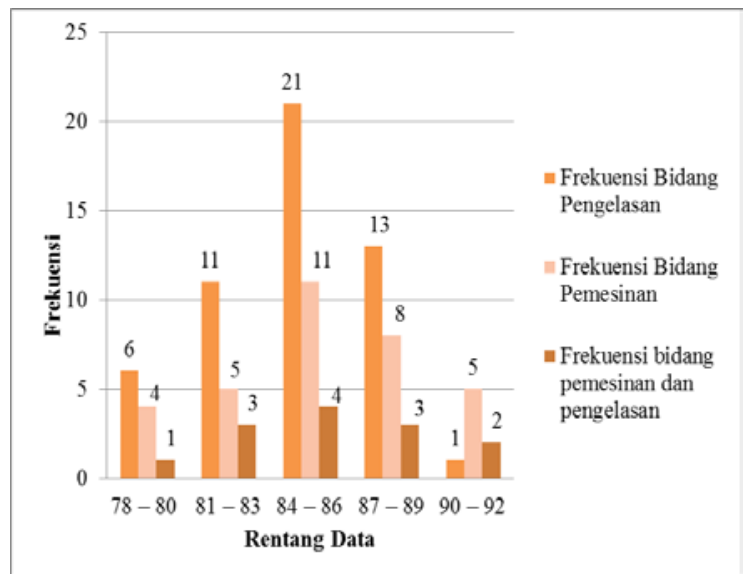

Gambar 8. Histogram data nilai praktik industri menurut bidang pekerjaan.

Dari data tersebut dapat diketahui bahwa frekuensi nilai praktik industri menurut bidang pekerjaan siswa menunjukkan, nilai tertinggi dengan frekuensi siswa terbanyak terdapat pada bidang pekerjaan pemesinan, nilai terendah dengan frekuensi siswa terbanyak pada bidang pekerjaan pengelasan, dan frekuensi bidang pekerjaan pemesinan serta pengelasan memiliki 
frekuensi yang tersebar hampir merata di setiap rentang data.

Kemudian disajikan pula diagram kecenderungan nilai praktik industri siswa, digambarkan pada Gambar 9.

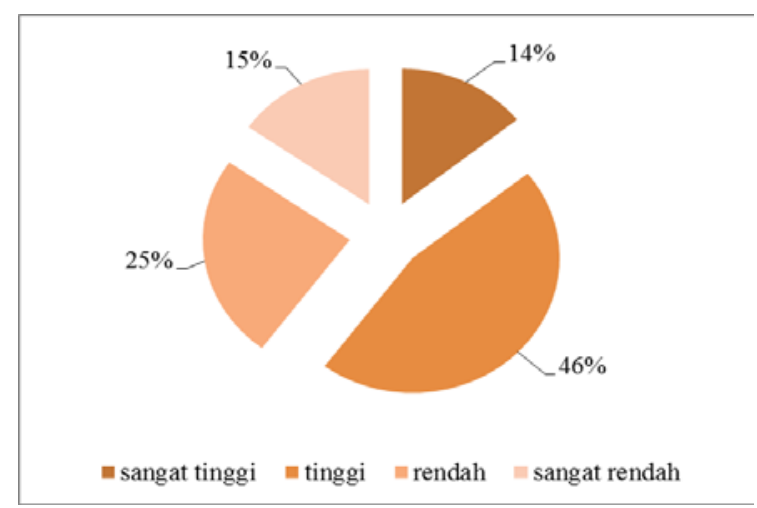

Gambar 9. Diagram kecenderungan nilai praktik industri siswa

Dari data tersebut dapat diketahui bahwa kecenderungan nilai praktik industri siswa teknik pemesinan, $14 \%$ termasuk kategori sangat tinggi, 46\% termasuk kategori tinggi, rendah $25 \%$ dan sangat rendah $15 \%$, dari data tersebut dapat disimpulkan bahwa rata-rata kecenderungan nilai praktik industri siswa termasuk kedalam kategori tinggi.

Keterlaksanaan praktik industri menurut bidang tempat praktik industri yang paling banyak adalah bidang pengelasan sebanyak 51 frekuensi (52\%), bidang pemesinan sebanyak 31 frekuensi (31,6\%), pemesinan dan pengelasan sebanyak 8 frekuensi $(8,2 \%)$ dan bidang lainnya adalah sebanyak 8 frekuensi (8,2\%). Keterlaksanaan menurut bidang pekerjaan siswa bidang pekerjaan terbanyak pada bagian pengelasan dengan 52 frekuensi (53,1\%), bidang pekerjaan pemesinan sebanyak 33 frekuensi (33,6\%), dan bidang pemesinan serta pengelasan sebanyak 13 frekuensi (13,3\%).

Kecenderungan keterlaksanaan praktik industri menunjukkan bahwa 28 siswa (28,57\%) termasuk kedalam kategori sangat tinggi, sebanyak 68 Siswa (69,38\%) kategori tinggi, dan 2 siswa (2,05\%) kategori rendah. Sehingga rata-rata dari persentase tersebut, dapat dikatakan bahwa siswa menyetujui keterlaksanaan praktik industri siswa Teknik Pemesinan SMK Muhammadiyah 1 Bantul ratarata termasuk kedalam kategori tinggi. Kategori tinggi ini didapatkan dari jawaban siswa yang mampu menjawab indikator seperti pemahaman siswa tentang praktik industri, pengetahuan mengenai kegiatan pra praktik industri, pengetahuan, keterampilan dan sikap kerja yang diperoleh dari dunia usaha/dunia industri selama praktik industri, fasilitas yang ada di tempat praktik industri, mentoring dan pembimbingan di industri, mentoring oleh guru dari sekolah, evaluasi jalannya praktik industri yang dilakukan oleh guru pembimbing dan pembimbing industri.

Dari hasil penelitian terhadap siswa kelas XII Teknik Pemesinan SMK Muhammadiyah 1 Bantul menunjukkan bahwa praktik industri memiliki pengaruh yang positif dan signifikan terhadap kesiapan kerja. Sesuai data sampel $\mathrm{N}=98$ didapatkan hasil perhitungan korelasi yang positif antara praktik industri dengan hard skill siswa sebesar 0,716. Jadi terdapat korelasi yang positif sebesar 0,716 antara praktik kerja industri dengan kesiapan kerja dan nilai korelasi 0,716 termasuk pada kategori. selain itu berdasarkan Tabel 1 interprestasi tingkat korelasi (hubungan) antara praktik kerja industri terhadap hard skill dalam kategori tinggi.

Hasil dari perhitungan regresi sederhana dapat dilihat data pada Tabel 2. Menggunakan Persamaan 1, diperoleh data persamaan regresi yang menunjukkan bahwa setiap nilai praktik industri (X) meningkat 1 poin maka hard skill (Y) akan meningkat 0,229.

Tabel 2. Hasil regresi sederhana

\begin{tabular}{cc}
\hline Variabel & Koefisien \\
\hline $\mathrm{X}$ & 0,229 \\
Konstanta & 1,541 \\
$r$ & 0,716 \\
$\mathrm{R}^{2}$ & 0,513 \\
thitung $_{\text {Signifikansi (P) }}$ & 10,060 \\
\hline
\end{tabular}


Koefisien determinasi $\left(\mathrm{R}^{2}\right)$ sebesar 0,513 nilai tersebut berarti $51,3 \%$ perubahan pada variabel hard skill (Y) dapat diterangkan oleh variabel pelaksanaan praktik industri (X), sedangkan $48,7 \%$ dijelaskan dengan variabel lain.

Berdasarkan uji t diperoleh nilai $\mathrm{t}_{\text {hitung }}$ sebesar 10,060. Jika dibandingkan dengan $t_{\text {tabel }}$ yang didapat dari tabel t sebesar 1,988 Pada taraf signifikansi $5 \%$, maka nilai $t_{\text {hitung }}>t_{\text {tabel }}$ dan $(P) \quad 0,00<0,05$. Sehingga hipotesis diterima, hal ini berarti bahwa pelaksaan praktik industri $(\mathrm{X})$ berpengaruh positif dan signifikan dengan hard skill (Y).

Bidang pekerjaan memiliki pengaruh yang tinggi terhadap nilai praktik industri siswa hal ini menunjukkan bahwa sebanyak 14 siswa (14,3\%), kategori tinggi sebanyak 45 siswa (45,9\%), kategori rendah sebanyak 24 siswa (24,5\%), dan sangat rendah sebanyak 15 siswa (15,3\%), dilihat dari persentase tersebut maka dapat dikatakan bahwa rata-rata siswa teknik pemesinan menyetujui bidang pekerjaan memiliki pengaruh yang tinggi terhadap nilai praktik industri dan rata-rata siswa menyetujui bahwa bidang pekerjaan yang mereka kerjakan di tempat praktik industri memiliki pengaruh positif terhadap nilai praktik industri yang siswa miliki. Sehingga dapat disimpulkan bahwa semakin tinggi pelaksanaan praktik industri, maka semakin tinggi pula hard skillnya dan bidang pekerjaan memiliki pengaruh tinggi terhadap nilai praktik industri siswa teknik pemesinan

\section{SIMPULAN}

Berdasarkan sajian data dan pembahasan, maka dapat disimpulkan bahwa: a) tingkat keterlaksanaan praktik industri siswa termasuk kedalam kategori tinggi, b) praktik industri berpengaruh positif dan signifikan terhadap hard skill siswa. Kesimpulan di atas dapat dinyatakan bahwa pelaksanaan praktik industri siswa kelas XII Teknik Pemesinan berpengaruh terhadap hard skill siswa.

\section{DAFTAR RUJUKAN}

Dalhari. 2016. Pengaruh pengalaman praktik kerja industri dan kemampuan praktik produktif terhadap minat berwirausaha. Jurnal Pendidikan Vokasional Teknik Mesin. 4 (8). 529-534.

Djandji Purwanto. 2013. Manajemen kerjasama antara sekolah menengah kejuruan dengan industri. Diakses tanggal 27 september 2017 dari http:// http://www.vedcmalang.com/pppptkboe mlg/index.php/menuutama/edukasi/488manajemen-kerjasama-antara-sekolahmenengah-kejuruan-dengan-industristudi-kasus-di-smkn-1-program-keahlianalat-berat-singosari-malang

Dwi Sapitri Iriani, dkk. 2015. Evaluasi pelaksanaan praktik kerja industri siswa kompetensi keahlian jasa boga SMK N 3 Purworejo. Jurnal Pendidikan Teknologi dan Kejuruan. 22 (3), 274-290

Hari Din Nugraha. 2017. Pengaruh bimbingan karir dan praktik kerja industri terhadap kesiapan kerja siswa teknik pemesinan SMK N 2 Pengasih. Jurnal Pendidikan Teknik Mesin. 5 (1). 65-74

Lehan Bagaswana. 2014. Pengaruh Soft Skills terhadap Prestasi Praktik Kerja Industri Siswa Jurusan Teknik Gambar Bangunan Tahun Ajaran 2013/2014 SMK Negeri 2 Depok Sleman. Skripsi. Yogyakarta: Fakultas Teknik Universitas Negeri Yogyakarta.

S. Basir. 2011. Soft Skill vs Hard skill. Jakarta Timur: Kantor Akuntan Publik Syarief Basir dan Rekan.

Sugiyono. 2013. Metode Penelitian Pendidikan (Pendekatan Kuantitatif, Kualitatif dan $R \& D)$. Bandung: Alfabeta

Suharsimi Arikunto. 2013. Prosedur Penelitian Suatu Pendekatan Praktik. Jakarta: Rineka Cipta.

Wardjiman Djojonegoro. 1998. Pendidikan dan Pelatihan Kejuruan Dalam Era Kompetensi Global. Jakarta: PT. Jayakarta Agung Offset. 